\title{
Some Thoughts on the Military Capabilities of Alexios I Komnenos: Battles of Dyrrachion (1081) and Dristra (1087)
}

Marek Meško

(Masaryk University)

\begin{abstract}
Alexios I Komnenos belongs to the most important emperors of the Byzantine history. Yet, in many respects, this period still remains an underdeveloped field of study. This paper attempts to review one of the aspects of his reign, namely his capabilities as a military commander since he owed much of his success in restoring the fortunes of Byzantium to his strong military background. In order to succeed in the final evaluation, most of the relevant military events during Alexios Komnenos' life and career in which he took personal part will be briefly reviewed and taken into consideration. Particular cases where Alexios Komnenos was allegedly responsible for a serious military defeat will be discussed in more detail (e.g. battle of Dyrrachion in 1081 and battle of Dristra in 1087) in order to assess whether it was solely Alexios Komnenos' responsibility, or whether the causes of defeat were not result of his faulty decision-making as a military commander.
\end{abstract}

\section{Keywords}

Byzantine Empire; Alexios Komnenos; military; battles; medieval warfare 


\section{Introduction}

The Byzantine emperor Alexios I Komnenos (1081-1118) is a very well-known character of the Byzantine history. At the same time, he is famous as the emperor who sat on the throne of Byzantium when the crusaders of the first crusade headed east to liberate Jerusalem. As such, Alexios Komnenos is quite familiar not just to researchers of the Byzantine history but also to scholars dedicated to the history of the Latin West. Paradoxically, it seems that the crucial importance of his personal input to the general history of both Byzantium and Western Europe has been unrecognized judging by the relatively little volume of scholarly work concerning his person, although this attitude started to change slowly since the 1970 s and 1980 s. $^{1}$ There are still important lacunae though, which seem to be very illogical, given the fact that his reign is considered unanimously as one of the turning points of the Byzantine history. ${ }^{2}$ It is also evident that Alexios Komnenos achieved much of his renewal of the fortunes of Byzantium thanks to his military background and skills ${ }^{3}$, and yet there is practically not a single article or a monograph (apart from a few scattered general remarks and two more complex evaluations by G. Buckler ${ }^{4}$ and J. Birkenmeier ${ }^{5}$ ) dedicated solely to Alexios Komnenos' military capabilities. Also the complex description and analysis of most of the battles (with the notable exception of the battle of Dyrrachion) ${ }^{6}$ Alexios Komnenos fought during his long reign is still missing. The present article represents the ambition of slightly altering this state.

Because of the limited space at my disposal, this effort will remain incomplete and probably not very complex. I will attempt to take into account all the relevant military events during Alexios Komnenos' life and career in which he took personal part, but only battles of Dyrrachion and Dristra will be explored in more detail in order to support my arguments. Other events over which Alexios Komnenos exercised only distant control from Constantinople or elsewhere will not be discussed at all. Another significant limitation derives from the fact that there is not enough space to compare extensively, or to comment on, all Alexios Komnenos' actions from the point of view of Byzantine military manuals that were written during the period between the $7^{\text {th }}$ and $11^{\text {th }}$ Centuries (e.g. Strategikon by Maurikios, Taktika by Leo VI the Wise, etc.). ${ }^{7}$ There exist only two

1 See Mullett - Smythe (1996).

2 Mullett (1996: p. 2), Frankopan (2007: p. 1).

3 Haldon (2001: p. 137), Birkenmeier (2002: p. 47), Mullett (1996: p. 2). There are also scholars that are evidently less impressed with Alexios Komnenos' military skills, or even doubt that his reign can be perceived as a success. See Treatgold (1995: p. 218).

4 G. Buckler's evaluation is full of interesting details but it gives too much attention to the outward signs and appearances connected with supreme military command and completely leaves out military capabilities. It is also quite obsolete by modern standards. See Buckler (1968: pp. 369-375).

5 Birkenmeier (2002: p. 80-84).

6 See for instance Haldon (2001: pp. 133-137), or Theotokis (2014: pp. 154-164).

7 See more Kolias (1997: p. 163). For the full overview of Byzantine military writings available today and extant secondary literature connected with them see Hunger (1978: pp. 321-340). 
attempts so far to conduct such an analysis in direct connection to Alexios Komnenos, but in my opinion their results remain rather inconclusive. ${ }^{8}$ One of the reasons is the fact that there is no solid support in the narrative sources that Alexios Komnenos read and subsequently acted on the battlefield in concordance with pieces of advice included in such manuals. ${ }^{9}$ Therefore, my attempted evaluation will be based on a rather simple win/lose criterion and Alexios Komnenos' actions such as they are described in historical accounts with very few references relating to Byzantine military handbooks. Particularly in cases where Alexios Komnenos was allegedly responsible for a serious military defeat I will try to determine what this emperor could really influence with his decisions and therefore military actions at any given moment, and what factors could possibly play important role in his decision making.

\section{Alexios Komnenos' Military Background}

Alexios Komnenos (born probably in 1057) ${ }^{10}$ was an offspring of important Byzantine family of Komnenoi. ${ }^{11}$ Most of the known male members of this family including its first representative Manuel Komnenos Erotikos (born ca. 955/960-1020) ${ }^{12}$ chose to pursue military career and Alexios Komnenos was no exception. His military education started in earnest before he achieved the age of $14 .{ }^{13}$ During these first years he would follow his older brother Isaakios (born ca. 1050). ${ }^{14}$ Military education of young Byzantine aristocrats comprised cavalry skills, using of bow and arrow, shield, lance, mace and fencing (and of course hunting). After mastering fighting techniques they were also usually encouraged to acquire more practical knowledge through commanding small units ${ }^{15}$ and imitating tactical and strategic decision-making of already seasoned and experienced Byzantine generals. ${ }^{16}$ This could be basically achieved mostly through direct observation of their superior military commanders (which could be also their relatives; fathers,

8 Price (2005), Alexopoulos (2008-2012).

9 Anna Komnena mentions only once that her father read and used the treatise on military tactics by Claudius Aelianus. Alexias, p. 469. For possible other written sources of his military knowledge and skills see Alexopoulos (2008-2012: pp. 51-52, n. 19). There exist few pieces of information that Byzantine emperors were storing, collecting, or even actually using various military handbooks. The most famous among them were the emperors Konstantine VII Porphyrogennetos (945-959) and Basileios II the Bulgar Slayer (976-1025). For further details and bibliography see Kolias (1997: pp. 158-159).

10 Bap〈ós (1984: p. 87).

11 About the origins of this illustrious Byzantine family see Bap〈ó (1984: pp. 25-26), Cheynet (1996: pp. 218-219).

12 Bapłóc (1984: pp. 25, 38). See also Cheynet (2006: p. 6).

13 It was at the age of 14 when a young Byzantine aristocrat would usually participate in his first military campaign. See Bapłós (1984: p. 62, n. 4).

14 Alexias, p. 12.

15 This is how the military education of Alexios' father John and his uncle Isaakios is described by Nikephoros Bryennios, see Bryen., pp. 75-77.

16 Haldon (2001: p. 63). 
uncles, older brothers, etc.) while taking part in military campaigns, or through reading military handbooks, which besides tactical maneuvers and unit formations also included descriptions of famous battles of the Greek and Roman past. ${ }^{17}$ There is no doubt that young Alexios was exposed to similar military education during his formative years to-

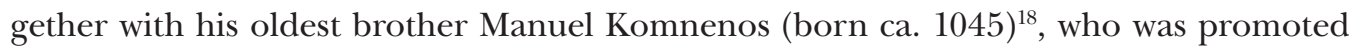
to the rank of kouropalatês and became domestikos of the East (also second in command after the emperor) in 1070 as a logical role model to imitate. After Manuel died prematurely in the spring of $1071^{19}$, Alexios was more than enthusiastic about joining the ranks of the army, but the emperor Romanos IV Diogenes (1068-1071) prevented his participation in the fateful Mantzikert campaign because of his young age (Alexios was only 14 at that time $)^{20}$ and probably also because of his still unfinished and therefore inadequate military education and training. Alexios Komnenos did not have to wait very long in order to see real combat action, because only two years after the Mantzikert campaign he was finally allowed to fight the Seljuk Turks in Kappadokia. From this moment on his combat record becomes impressive. Since this campaign of 1073 led by Alexios' older brother Isaakios until Alexios' natural death in 1118 Alexios Komnenos participated in person in more than 21 military campaigns in total and was at the head of the Byzantine army in at least 12 field battles (not to mention numerous skirmishes) ${ }^{21}$, a fair number of which deeply affected the course of the Byzantine history. His military career can be divided into three subsequent periods: 1) 1073-1081, 2) 1081-1095, and 3) 1095-1118. The initial period is marked with successes against several military capable rebels against the imperial rule (Rousell of Bailleul, Nikephoros Bryennios and Basilakios). ${ }^{22}$ The second period after his successful bid for imperial throne is known for some of his worst military failures and the third period starting with the arrival of the crusaders is again highlighted by renewed military victories.

\section{Alexios I Komnenos as a military commander}

While there can be little doubt about the quality of Alexios Komnenos' military skills before his ascension to the imperial throne in 1081, it is difficult to understand what

17 For example the Tactica by Claudius Aelianus, which was also read by Alexios Komnenos (see note 9 above), included descriptions of several famous battles of the ancient past (e.g. battle of Leuktra, battle of Mantinea, battle of Cannae, etc.). Ael., pp. 173-185. Byzantine elite was familiar with many ancient military histories and deeds of famous generals, see for instance Alexias, p. 12. It was an integral part of their cultural Romano-Byzantine heritage.

18 Bapłós (1984: pp. 61-64).

19 Bryen., p. 103, Alexias, p. 11, Bap̧ós (1984: p. 63).

20 Alexias, p. 11; Frankopan (2012: p. 34).

21 This estimate is based on the lecture of three main Byzantine written sources for Alexios Komnenos' reign, Hylē historias by Nikeforos Bryennios, Epitomē historiōn by John Zonaras, and finally Alexiad by Anna Komnena.

22 Frankopan (2012: pp. 33-34). Since this period took place before Alexios Komnenos ascension to imperial throne, it will not be discussed further. 
exactly went wrong during the first decade of his reign. Serious, almost catastrophic military defeats at Dyrrachion (1081 $)^{23}$ and Dristra $(1087)^{24}$ are the most famous examples of Alexios Komnenos' failures and will be discussed below. In both cases, it was undoubtedly Alexios Komnenos alone who had the overall command over Byzantine units and, therefore, at the first glance it would seem that whatever military skills he had prior to 1081, they were no longer available to him after this date. In fact, he did the exact opposite of the expectations the Byzantine elites placed in him when he was allowed to organize his bid for imperial throne. Since the assumption that Alexios Komnenos' military skills somehow deteriorated practically overnight is absurd, the main part of our discussion about this emperor as a military commander will be dedicated to possible explanations of Alexios' military failures at Dyrrachion and Dristra (as the most obvious examples) during the first decade of his reign. Moreover, Alexios Komnenos "regained" his capabilities as a military commander after 1091 when he managed to inflict a heavy defeat to the Pechenegs in the battle of Lebounion. Thus, this period will not be explored in detail in our final discussion.

The most spectacular and one of the earliest blunders that Alexios Komnenos suffered as the Byzantine emperor and supreme commander of the Byzantine army was the defeat from the hands of the Norman duke Robert Guiscard in the battle of Dyrrachion (18 ${ }^{\text {th }}$ October 1081). Most modern commentators agree that the battle was lost because of general bad cohesion of Byzantine units ${ }^{25}$ and more specifically because at one point Alexios Komnenos lost control over his key units (Varangian guard). ${ }^{26}$ Nevertheless, this kind of failure can happen even to the most talented military commander and does not mean that such and such general is unfit for the battle command. In order to learn about Alexios Komnenos' qualities as a military commander one has to ask another crucial question which has been addressed less intensively than the previous questions. We must ask why Alexios Komnenos decided to engage the Normans head-on in the first place (direct approach) when he could just block the mountain passes to the interior, use the Venetians to cut-off the Norman naval communications and let them starve as he did later against Bohemund (indirect approach). ${ }^{27}$ In the Alexiad, Anna Komnena attempts to minimize the blame for this decision placed on her father by describing a war council of her father and his military commanders that took place before the battle during which the decision to attack finally materialized..$^{28}$ But her attempt to put the blame for instant

23 Modern city of Durrës in Albania.

24 Today Silistra in Bulgaria.

25 Haldon (2001: p. 135), Theotokis (2014: p. 157), Bünemann (1997: pp. 126-127).

26 See Haldon (2001: p. 135), Birkenmeier (2002: p. 63), Theotokis (2014: p. 161). This argument is based on Anna Komnena's description of fateful Varangian charge during the battle during which they detached themselves from the ranks of the Byzantine battle formation, and then they were cut-off, surrounded, and finally exterminated by the advancing Normans. Alexias, p. 134. On Varangian guard in general see Blöndal (1978). See also text below.

27 This is also a course of action that is recommended in Byzantine military manuals, see Kekaumenos, p. 95.

28 Alexias, pp. 129-130. 
attack on some of the Alexios' younger commanders is in fact misleading because it was Alexios Komnenos as the supreme commander who had the last word. ${ }^{29}$

From modern comments one can gain the impression that this decision was at least foolhardy from the very start (it is also presented as the result of Alexios' young age and relative inexperience ${ }^{30}$ ), because Robert Guiscard's Normans were better equipped, trained, motivated and experienced, and enjoyed numerical superiority. ${ }^{31}$ In contrast, in their minds the Byzantine units marked by disarray caused by one decade of civil wars $^{32}$ were rather disorganized, composed of unreliable mercenaries of various origins, domestic Byzantine units were less battle-worthy, and surely not in the position to withstand the formidable charge of Norman heavy cavalry. ${ }^{33}$ I argue that the reality was slightly different. In fact, it seems that it was Alexios Komnenos who enjoyed superiority in numbers over Norman invaders. According to modern estimates, the Byzantine emperor could muster as much as 18-20,000 men for the campaign in Epirus. ${ }^{34}$ The core of the Byzantine army were, apart from elite guard units from the Byzantine capital ${ }^{35}$, the Western tagmata from the Balkans ${ }^{36}$, also units which were in fact the least affected by the post-Mantzikert negative developments. The Norman army most probably counted of only $15,000 \mathrm{men}^{37}$, from which, according to written sources, only 1,300 were battlehardened knights (heavy cavalry). ${ }^{38}$ The rest of the men were recent peasant recruits from all over of southern Italy ${ }^{39}$, Salerno militias ${ }^{40}$, mercenaries and knights belonging to personal retinues of other Norman barons (as well as a handful of adventurers from

29 Although with some restrictions. See note 56 below.

30 Angold (1997: p. 132). Although M. Angold mentions Alexios Komnenos' foolhardiness in connection with later campaign against the Pechenegs in 1087 he attributes it to his "early years" thus also including campaign of Dyrrachion in 1081.

31 For instance see Haldon (2002: p. 134). This traditional view derives from Anna Komnena's statement that the Norman host comprised 30,000 men. See Alexias, p. 51.

32 Dawson - McBride (2007: p. 7).

33 Heath - McBride (1979: p. 30), Birkenmeier (2002: p. 57).

34 Haldon (2001: p. 134). J. Birkenmeier and J.-C. Cheynet are suggesting even higher figure between 20,000 and 25,000 men. Birkenmeier (2002: p. 62), Cheynet (1995: p. 331). R. D'Amato made an assumption that Alexios Komnenos had as much as 50,000 men (!). D'Amato - Rava (2010: p. 9).

35 Varangian Guard, Exkoubitai and Bestiaritai. Haldon (2002: p. 134).

36 Among the units were the tagmata from Macedonia and Thrace, and Thessalonica (Thessaly). Alexias, p. 126, Haldon (2001: p. 134).

37 Orderic Vitalis records some 10,000 men in Robert Guiscard's invading forces see Ord Vit., p. 16. Anna Komnena states that the Normans used to transport the whole host from Apulia to Epirus on board of 150 ships. Each ship could carry 200 soldiers. This would mean that the Norman host comprised 30,000 men - a figure Anna Komnena indeed presents in the Alexiad. See Alexias, pp. 50-51, Buckler (1968: p. 356). However, not all 150 vessels were transports, some 50 were galleys. Guil. Apul., p. 214. This would decrease the maximum number of Norman soldiers transported to Epirus down to 20,000, but this number was probably even more reduced, given the fact that Anna Komnena usually tends to exaggerate. All in all, 15,000 is a plausible estimate for the strength of the whole Norman army.

38 Malaterra, p. 583.

39 Ord Vit., p. 16, Guil. Apul., p. 210.

40 See Eads (2005: p. 85). 
the kingdom of France and Normandy ${ }^{41}$ ) and even sailors from the Norman fleet. ${ }^{42}$ In particular, the battle-worthiness of fresh recruits from Apulia mentioned above or the sailors inexperienced in land warfare, which probably composed a very large proportion of the entire Norman infantry, was surely very low. Furthermore, the loyalty of some units under Robert Guiscard's command was far from being unconditional, for example the already mentioned militia from Salerno ${ }^{43}$, or armed retinue of count Amicus II of Giovinazzo. ${ }^{44}$

I believe that Alexios Komnenos knew all of this about his adversaries, and probably even more than the bits of information preserved until our times. His use of spies and various intelligence tricks throughout the war against the Normans and during his whole reign is well documented..$^{45}$ This conclusion becomes even more corroborated if we follow closely the precautions Alexios Komnenos was taking before the battle itself. As they were not as discussed in such a detail as the battle of Dyrrachion itself by most of the historians they merit our closer attention. First, it is known that byzantine troops were approaching from the direction of the so-called Kake pleura and the valley of the Charzanes river (today Erzen in Albania). Alexios Komnenos did not advance as far as Dyrrachion first and let his soldiers to build a camp some $9 \mathrm{~km}$ from the besieged city. ${ }^{46}$ From there he sent an embassy to Robert Guiscard ${ }^{47}$ (which constitutes a sound proof that by this moment Alexios Komnenos already knew the exact location of the Norman camp). In order to keep his adversary in the dark about the exact strength and position of his own forces Alexios Komnenos moved on $15^{\text {th }}$ October 1081 his entire army to a new position some $6 \mathrm{~km}$ south from Dyrrachion on the main road leading from Dyrrachion to Valona (Aulon). ${ }^{48}$ The new location close to the church of St. Nicolas ${ }^{49}$ had several major advantages; the Byzantines could directly observe the besieged city, they also could get easily in touch with allied Venetian navy units (sea shore was only a little distance away) $)^{50}$, and they also blocked the only overland communication route of Robert Guiscard with the rest of his troops occupying the southern parts of Epirus (Valona, Butrinto, etc.). From

41 Ord Vit., p. 16.

42 Guil. Apul., p. 224.

43 Robert Guiscard took Salerno only in 1077, so the loyalty of troops from this principality was at least questionable. According to one theory, the participation of Guiscard's wife Sichelgaita in this campaign was a means to ensure the supervision of Salernitan troops who would be more loyal to her (as a member of Salernitan princely family) than to her husband. Eads (2005: p. 84-85).

44 His presence in the Norman host is very peculiar. Count Amicus II of Giovinazzo (or Molfetta) was one of the Norman counts led by count Jordan of Capua that rebelled against Robert Guiscard only months before the start of the Epirus campaign (in 1079-1080). See Chalandon (1907: pp. 252-253).

45 See for instance Buckler (1968: pp. 390-391). For contrary opinion concerning use of spies and scouts by Alexios Komnenos see Theotokis (2014: pp. 154-155).

46 Alexias, p. 129. For more information about this area see Ducellier (1981: p. 16).

47 Alexias, p. 129.

48 Today Vlorë in Albania.

49 Alexias, p. 129. The localization of Byzantine camp was described in detail and identified by A. Ducellier, see Ducellier (1981: p. 35). See also Bünemann (1997: p. 122).

50 Alexias, p. 129. 
this position Alexios Komnenos devised an ingenious battle plan according to which the more numerous Byzantine troops would launch a surprise attack on Norman camp under the walls of Dyrrachion from three different directions shortly before the dawn of $18^{\text {th }}$ October $1081 .{ }^{51}$ Only a mysteriously gained foreknowledge about this plan saved the Normans from almost certain defeat when Robert Guiscard suddenly led his army out of the camp to a new location close to the church of St. Theodore where the decisive battle was finally fought on $18^{\text {th }}$ October $1081 .^{52}$ It is therefore clear that Alexios Komnenos did not foolhardily attack the Normans head-on, but before the battle he did as much as possible to maximize chances for Byzantine victory.

Thus, Alexios Komnenos' decision to engage the Normans does not seem to have been such a fatal mistake as some commentators of the battle of Dyrrachion usually imply. Alexios Komnenos seemed to enjoy numerical advantage, he approached with his forces in a very controlled and cautious manner, and he most probably had a very sound tactical plan for the forthcoming confrontation. ${ }^{53}$ Moreover, as was mentioned above, the Norman troops were in no way monolithic, and in fact with their various degree of battle-readiness, combat value and loyalty issues mirrored Alexios Komnenos' own forces (as in any other typical medieval army). There are also some important additional reasons why Alexios Komnenos might have felt induced to engage the Normans in pitched field battle. The first was local and strategic and the second was actually of political nature. The Byzantine emperor was clearly worried about the situation of the besieged city of Dyrrachion. Prior to the battle, its commander - Georgios Palaiologos - kept sending messages about Robert Guiscard's progresses and composition of his host. ${ }^{54}$ The loss of such a commanding outpost would greatly play into the hands of the Normans and massively damage the interests of the Byzantines. ${ }^{55}$ The latter reason was connected with the fact that Alexios Komnenos became the emperor only very recently, having the task to protect the Empire. As a "miraculously" capable general he was supposed to achieve a very significant victory over the Normans quickly, in a similar way he managed to defeat rebellious generals before 1081. If Alexios Komnenos opted to use indirect approach and blockade the Normans in Epirus, this strategy would have probably ended the war in 1081 or 1082 (as was the case later against Bohemund in 1107/1108), but would not bring him any really quick and spectacular victory. This is possibly the main reason why Alexios Komnenos decided to face the Normans in battle, not because he was young, hot-headed, or inexperienced. Byzantine emperor simply opted for calculated risk and hoped for rapid success that would strengthen his position as the supreme

51 Alexias, p. 132, Haldon (2002, p. 134), Theotokis (2014: p. 155).

52 Guil. Apul., p. 224; Malaterra, p. 584. Reasons of this surprising action of Robert Guiscard remain a mystery until today. Historians mostly suppose an information leak from the Byzantine camp, infiltration of Byzantine camp by Norman spies (Birkenmeier (2002: p. 63), or an act of treason committed by one of the Byzantine allies.

53 Again the decisions and steps taken by Alexios Komnenos are in line with general recommendations for such a situation in various Byzantine military manuals, see for example Kekaumenos, p. 55.

54 Alexias, p. 122.

55 Birkenmeier (2002: p. 63). On importance of Dyrrachion see Ducellier (1981: pp. 3-4, 26-27). 
ruler in Constantinople and on the battlefield. ${ }^{56}$ But in this case, his usual luck abandoned him, his troops lost cohesion and the Byzantines were defeated.

As for the exposure of his own troops to the decisive charge of heavy Norman cavalry that is usually represented as one of the most important mistakes Alexios Komnenos committed during the battle of Dyrrachion ${ }^{57}$, there is need for more explanation. Although Alexios Komnenos did acquire some experience with Norman mercenaries during early stages of his military career (e.g. suppressing Roussel of Bailleul's rebellion and that of Nikephoros Bryennios), it paradoxically did not involve much of first-hand experience of heavy Norman cavalry charge on the battlefield. In 1075-1076 Alexios Komnenos was fighting the Normans by harassing small groups of Norman mercenaries by using indirect tactics and did not meet them in pitched battle. ${ }^{58}$ Only in 1078 during the battle of Kalavryai ${ }^{59}$ his own army comprised a several hundred strong detachment of Frankish (meaning Norman) cavalry from south Italy ${ }^{60}$ and the opposing forces of Nikephoros Bryennios also included another Norman cavalry unit known as Maniakatoi Latinoi. ${ }^{61}$ Subsequently this would be his first experience with Norman heavy cavalry tactics, but paradoxically it would not prepare him for situation he encountered later during the battle of Dyrrachion, because in 1078 he had at his disposal his own Norman cavalry force to counter the attack of the opposing heavy cavalry charge. This means that in the heat of the battle under the walls of Dyrrachion Alexios Komnenos' shortcoming was the direct consequence of the fact that even though he probably was in the position to envisage the effect the heavy cavalry charge would have on his troops, the lack of similar unit in his own formation did not allow him to counter this threat in the best way possible. He had to rely on his Varangians and their shield-wall instead. ${ }^{62}$ But even here

56 It is worth noting that Alexios Komnenos' position as the undisputed supreme military commander was very fragile during his first campaign as emperor. Under his command there were other high-ranking aristocrats closely associated with imperial power (hence with almost as strong claim to the imperial throne or better than Alexios Komnenos himself) that could have easily assumed the same position if he failed, such as Alexios' brother-in-law kaisar Nikephoros Melissenos (and his very recent opponent in the struggle for the imperial throne), porphyrogennètos Leo Diogenes (son of the emperor Romanos IV Diogenes), porphyrogennētos Konstantine (Konstantios) Doukas (younger brother of the emperor Michael VII Doukas and son of the emperor Konstantine X Doukas), and Nikephoros Synadenos, nephew of yet another emperor Nikephoros III Botaneiates. See Alexias, pp. 130, 132. This is also another reason why Alexios Komnenos decided to gather his war council on the eve of the battle, because he could not ignore opinions of such important figures.

57 For instance see Haldon (2001: p. 137).

58 Bryen., p. 185.

59 Today Gelivre in Turkey.

60 Bryen., p. 265, Tobias (1979: p. 198), Haldon (2001: p. 128).

61 Bryen., p. 267, Haldon (2001: p. 128). This unit was named after general Georgios Maniakes who rebelled against the emperor Konstantine IX Monomachos (1042-1055) in 1042. It was composed of Norman mercenaries from south of Italy. Kühn (1991: p. 258), Birkenmeier (2002: p. 75), Shepard (1993, pp. 283-284, n. 38).

62 Theotokis (2014: p. 218). Although there is one tactical measure taken by Alexios Komnenos before the battle of Dyrrachion that can be interpreted as a possible attempt to meet the Norman cavalry charge and repel it. It was the deployment of archers and light infantry behind the shield-wall of the Varangian guard. See Haldon (2001: pp. 134-135). 
the main reason why Norman heavy cavalry was finally able to crush the center of the Byzantine battle formation was the rather hot-headed advance of the Varangian Guard whose members instead of protecting the Byzantine front with its famous shield-wall started an ill-fated pursuit of the fleeing Norman right wing under count Amicus II of Giovinazzo. ${ }^{63}$ Only after they were drawn away from their position Robert Guiscard was able to order his knights to attack and thus to win the whole battle.

Another military failure within the scope of the defeat at Dyrrachion in 1081 that needs to be discussed in more detail is the campaign against the Pechenegs in Paradounavon (and the battle of Dristra in particular) in $1087 .^{64}$ This campaign and this particular battle are less-known to modern historians than the battle of Dyrrachion, although recently there have been some very exciting discoveries and also the actual location of the battlefield was determined by Bulgarian archeologists. ${ }^{65}$ During this campaign Alexios Komnenos basically managed to cripple his entire army which had been only recently renewed after the losses suffered during the war against the Normans. Especially the losses in the ranks of the Byzantine cavalry during and after the battle of Dristra were so severe that the Pechenegs were able to raid Byzantine territories south of the Haemus in the aftermath of the battle without any constraint - there was no one to stop them. ${ }^{66}$ The exact ratio of losses in this battle is extremely hard to estimate, but surely it was higher than at Dyrrachion against the Normans. The entire Byzantine army numbered ca. 15,000 men at Dristra. ${ }^{67}$ The Pechenegs were more numerous than the Normans; moreover, they were more persistent in pursuing the routed Byzantines than the Normans after Alexios Komnenos' army ranks broke and the soldiers started to flee. Anna Komnena mentions groups of soldiers being encircled and then taken prisoner or killed ${ }^{68}$ Many high-ranking officers (e.g. kaisar Nikephoros Melissenos Alexios Komnenos's brother-in-law ${ }^{69}$ ) were also captured and Alexios Komnenos only barely escaped the same fate. ${ }^{70}$

This failure is difficult to understand given the fact mentioned above that Alexios Komnenos was familiar with nomadic warfare from the very start of his military career. As such he should have been able to foresee the movements of his adversaries and to avoid confrontation under conditions favoring the enemy. Yet again, as in the case of the defeat at Dyrrachion, a set of questions arises: what were the motives for Alexios Komnenos to attack the Pechenegs and was this the reason why the whole campaign failed? How was Alexios Komnenos responsible for this failure? Before it is possible to answer these questions the strategic situation of the summer of 1087 needs to be explained

63 Alexias, p. 134, Haldon (2001: p. 135).

64 For the battle of Dristra see Alexias, pp. 211-215, Zonaras, pp. 735-736, Birkenmeier (2002: pp. 73-74), Meško (2012: pp. 170-178).

65 See for instance Йотов - Николов (2009: pp. 432-447).

66 Chalandon (1900: pp. 116-117).

67 See Meško (2012: p. 173).

68 Alexias, pp. 215-216.

69 For more details about Melissenos see Skoulatos (1990: pp. 240-245).

70 Alexias, pp. 214, 216. 
briefly in regard to the Pechenegs. There seems to be two separate major groups of the Pechenegs in the Balkans between 1053 and 1087.71 The former group was located in the Byzantine province of Paradounavon. The Paradounavon Pechenegs were under loose Byzantine control until 1074. After 1074, they took over Paradounavon and their leader Tatous replaced the Byzantine stratēgos in Dristra as exarchōn. ${ }^{72}$ At first, the Pechenegs were interested in peaceful coexistence with the Byzantines, but the fluid situation on the Lower Danube and the overall political crisis in the Empire pushed them to a series of attacks against Byzantine territories south of the Haemus (1077/1078-1086). ${ }^{73}$ The latter group is represented by the Pechenegs living in the lands north of the river Danube. They appear to have been divided into two separate groupings. Prior to 1085, the group led by a certain Kutesk was seriously weakened by their involvement in exHungarian king Salomon' (1057-1074) unsuccessful attempt to recuperate the Hungarian throne. Salomon then moved to the second group, which was led by the ruler named Tzelgu and, probably at Salomon's instigation, Tzelgu's Pechenegs attacked Byzantium in the spring of $1087 .{ }^{74}$ This attack was a complete failure and Tzelgu, together with Salomon, were killed along with many Pecheneg warriors. ${ }^{75}$ As a consequence, in the early summer of 1087, the only Pecheneg group strong enough to pose any threat to the Byzantines was that of the Paradounavon Pechenegs.

That, at least, seems to be the conclusion reached by Emperor Alexios Komnenos. With the Pechenegs north of the Danube out of his way, Alexios was probably convinced that the time had come to attack and finish off the last Pecheneg group resisting the restoration of the Byzantine power in the Balkans, namely the Paradounavon Pechenegs. He certainly felt that with one swift and powerful strike, while the Pechenegs were in disarray, he would be able to rectify the mistakes of the previous Byzantine emperors since the reign of Konstantine IX Monomachos (1042-1055). Anna Komnena, at least, attributes such a line of reasoning to her father. ${ }^{76}$ And again, although Alexios Komnenos was the only decision maker during this campaign, Anna Komnena describes in detail another military council where the attack against the Pechenegs in Paradounavon was discussed. And it was again Alexios' decision alone that set this fateful campaign into motion. ${ }^{77}$ Emperor's firm determination to definitely finish off the Pechenegs is shown in his subsequent military preparations, which were meticulously executed. His main strategic objective was Dristra - the heart of the Pecheneg power in Paradounavon. ${ }^{78}$ In order to cut off the Pechenegs from any help that might come from the lands north of the river, the emperor dispatched the Byzantine fleet upstream through the Danube

71 See Meško (2013: pp. 179-205).

72 Attal., p. 205; Meško (2013: p. 190).

73 Meško (2013: p. 197).

74 Meško (2013: p. 197). For the Pecheneg attack see Alexias, pp. 203-204.

75 Alexias, p. 204; Chron. pic., pp. 409-410. For more detailed description of the final fate of the ex-Hungarian king Salomon see Meško (2011: pp. 77-94).

76 Alexias, pp. 204-205. See also Meško (2013: pp. 198-199).

77 Alexias, pp. 205-206.

78 Dristra was the seat of the Pecheneg ruler Tatous. See note 72 above. 
delta. ${ }^{79}$ Meanwhile, he brought army units from almost the entire western half of the Empire, first to Adrianople (now Edirne in Turkey) and then to Lardea ${ }^{80}$, and submitted them to intense military training in order to increase their cohesion and battle readiness. ${ }^{81}$

It is now clear that what was the main mistake committed by Alexios Komnenos during this campaign was not its actual execution, which was almost in total accordance with earlier Byzantine military manuals, or a relative degree of inexperience of some of his only recently recruited troops which were performing particularly well during the entire campaign, but his overall optimistic estimation of the strategic situation before the campaign. Alexios Komnenos believed that the Pechenegs of Paradounavon were weak, disorganized and isolated. To a certain degree this was true, but what Alexios Komnenos failed to take into account was the fact that the Pechenegs still largely outnumbered his own forces. In this case, the Byzantine spies probably did not work with their usual effectiveness to the detriment of the Byzantines who did not know until the very last moment how many Pechenegs they will have to face in battle. Thus, the sight of another big mass (up to 36,000 warriors according to Anna Komnena, which is clearly an exaggeration) ${ }^{82}$ of Pecheneg reinforcements approaching the battle field after the Byzantine soldiers were fighting valiantly near Dristra since the morning until early afternoon was a fatal blow to their morale and the Byzantines broke formations and started to run. ${ }^{83}$ Not even the demonstration of Emperor's personal courage (who sprang in front of his panicking soldiers in order to bolster their wavering morale) could stop Byzantine units from fleeing. ${ }^{84}$ All in all, Alexios Komnenos' decision to fight the Pechenegs was from the military point of view a very sound and logical one, but the Byzantines failed to gather intelligence prior to the battle and this resulted into heavy defeat. ${ }^{85}$

Once again, in the aftermath of the battle of Dristra, Alexios Komnenos was obliged to switch from direct to indirect approach and to very intense and shrewd use of long distance diplomacy, which eventually brought about an alliance with another powerful group of steppe nomads - the Cumans. ${ }^{86}$ Before the Byzantino-Cuman military alliance finally materialized in the spring of 1091, Alexios Komnenos had to rely solely on his own shaken forces. He avoided battles and only attempted to harass his enemies whenever a propitious opportunity arose. His personal presence in Thrace during the years 1088-1091 clearly shows that the very survival of the Empire was at stake. ${ }^{87}$ Alexios Kom-

79 Alexias, pp. 204, 207; Diaconu (1970: p. 117).

80 Byzantine Lardea can probably be located to present-day Lozevec in Bulgaria. See Soustal (1999: p. 333).

81 Alexias, p. 204.

82 Alexias, p. 212, Chalandon (1900: p. 116), Diaconu (1970: p. 119).

83 Alexias, p. 212, Birkenmeier (2002: p. 74).

84 Alexias, pp. 212-213.

85 See also discussion below.

86 Alexias, p. 216, Birkenmeier (2002: p. 74). There are still scholars who defend the traditional narration by Anna Komnena about how the arrival of the Cumans "surprised" Alexios Komnenos. See Kovács (2014: p. 179).

87 See Meško (2007: pp. 3-27). 
nenos also became extremely cautious, even paranoid, about the safeguarding of his own troops during this period. This stance is clearly demonstrated by his actions prior to the battle of Lebounion in Thrace ${ }^{88}$, where Alexios Komnenos was taking care in person about choosing the right location for the camp of his troops and its safety in case the Pechenegs (but also his unreliable Cuman allies) suddenly attacked. He also relocated the whole army several times, so as its position remained undetected by Pecheneg scouts. And finally he was very hesitant about risking everything in the pitched battle against the Pechenegs and was actually forced to join in by his more warlike Cuman allies led by khans Togortag and Boniak. ${ }^{89}$ This is understandable as he could not afford to lose them - there were practically no more reserves except of hiring foreign mercenaries.

There is another question connected with our attempt to understand whether Alexios Komnenos was or was not a good military commander. I assumed that he had some part in the failure in the battle of Dyrrachion and the battle of Dristra; in his former encounter he did not immediately recognize the danger of Norman heavy cavalry charge, and during the latter he most probably failed to acquire proper reports on the strength of his opponent. A bad or average military commander usually repeats his mistakes because he is unable to learn from his bad decisions. Did Alexios Komnenos repeat his own mistakes or did he learn from them? Is it possible to track any hint of improvement of his military skills over time? I believe that in the case of dealing with the Norman cavalry charge it is possible to discern such an improvement. At Dyrrachion in 1081 Alexios Komnenos was rather unprepared for what the Norman knights could unleash upon his troops. Once Alexios Komnenos acquired first-hand experience of such attacks, he attempted to avoid it at all cost during next engagements, or even counter it with various measures, although firstly without success (e.g. in the battle of Joannina and probably Arta in which the Byzantines were defeated). ${ }^{90}$ Only when he chose to return to his own tactics of indirect approach, for which he became famous before 1081, the Normans suffered their first defeat in a series of encounters and skirmishes in the vicinity of Larissa in April 1083. ${ }^{91}$ According to both Byzantine and Norman written sources Alexios Komnenos divided his army comprising units of infantry and light cavalry including

88 For the full account of the battle see Alexias, pp. 245-249, Meško (2012: pp. 170-178), Frankopan (2012: pp. 37-38).

89 See Alexias, pp. 243-246, Chalandon (1900: p. 133). Both Cuman khans are also well known from the Russian Primary Chronicle. See Nestor, p. 179 ff (Togortag), p. 182 ff (Boniak).

90 During the battle of Joannina Alexios Komnenos intended to obstruct the Norman cavalry charge with obstacles created by light chariots with spears pointed outwards pushed in front of the Byzantine battle formation. But his plan did not work because Bohemund ingeniously countered by attacking from both flanks and avoiding the area protected by chariots. See Alexias, p. 150; Guil. Apul., p. 236. In the next engagement near Arta Alexios Komnenos attempted to protect his formation by the use of iron caltrops. Bohemund again attacked unexpectedly from flanks. Alexias, p. 151. See also Birkenmeier (2002: pp. 67-68), Theotokis (2014: pp. 170-171), Alexopoulos (2008-2012: pp. 50-52).

91 For the battle of Larissa see Alexias, pp. 156-161, Birkenmeier (2002: p. 68), and also Theotokis (2014: pp.

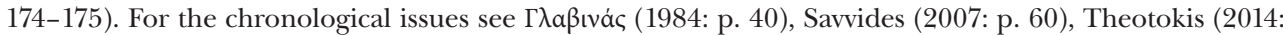
p. 173). 
7,000 Seljuk horse archers ${ }^{92}$ and other Turkish mercenaries (probably the Uzes) ${ }^{93}$ into two parts, and used one led by Nikephoros Melissenos and Basileios Kourtikios to lure away the Norman heavy cavalry led by Bohemund far from the Norman camp ${ }^{94}$ which he subsequently attacked and destroyed with the rest of his troops. ${ }^{95}$ The Norman baggage train, supplies and siege machines fell into the hands of the Byzantines ${ }^{96}$ and even when the following encounters around Larissa were rather inconclusive, the loss of the camp forced Bohemund to withdraw within a short time span and thus to recognize his first serious defeat. Also later in Alexios Komnenos' reign the western heavy cavalry charge represented a well-known feature to him and, therefore, he was able to counter it (or to avoid it) with success. The most significant example of this understanding represents the campaign against Bohemund in Epirus in 1107/1108. The Normans were simply not allowed to use their supreme heavy cavalry tactics this time and they lost the whole campaign.

In the case of the battle of Dristra, the conclusion is less straightforward. Although Anna Komnena describes this campaign in detail, she does not mention spies and scouts that must have accompanied the Byzantine army at all. I have already mentioned that Alexios Komnenos usually used such troops rather extensively throughout his entire reign (and even before his ascension to the imperial throne).$^{97}$ This means that there were probably other reasons that were beyond his personal control why his scouts failed to collect necessary pieces of information. It is possible only to speculate what went wrong. Anna Komnena mentions repeatedly that since the crossing of the Haemus the Pechenegs were constantly harassing every Byzantine soldier that left the relative safety of the Byzantine army marching formation or marching camp, when the Byzantines stopped for night. She only refers to soldiers that were trying to get some fodder for horses and pack animals ${ }^{98}$, but it is not improbable that actual spies were among them that were attempting to do their job. They failed to perform it because of the strong Pecheneg presence in the area. What is sure from the description of later campaigns (after 1087) of Alexios Komnenos against highly mobile nomadic opponents (the Pechenegs, the Cumans, and the Seljuk Turks) is the fact that he mostly seemed to enjoy rather good knowledge about their movements and whereabouts which he subsequently used to his own advantage. ${ }^{99}$ Thus, it seems that the campaign against the Pechenegs in Paradou-

92 Alexias, p. 154, Chalandon (1900: p. 89), Savvides (2007: p. 59).

93 The presence of the Uzes within the ranks of the Byzantine army is indicated by the presence of their commander Ouzas. Alexias, p. 160.

94 For this purpose Alexios Komnenos gave his imperial insignia and mount to his younger brother Adrianos. See Alexias, p. 156, Zonaras, pp. 735-736.

95 See Alexias, p. 158, Guil. Apul., p. 238, Chalandon (1900: p. 90).

96 Guil. Apul., pp. 238, 240, Bünemann (1997: p. 151).

97 See note 45 above.

98 Alexias, pp. 208-209.

99 There are many examples of intelligence gathering or intelligence reaching Alexios Komnenos in the Alexiad, very often introduced with the verb mathein (to learn by inquiry, to ascertain). For instance during opening stages of the Cuman attack in 1095 Alexios Komnenos was repeatedly informed about their 
navon in 1087 represents an exception, rather than a rule, another stroke of bad luck, rather than blatant incompetence on Alexios Komnenos' part.

\section{Conclusion}

According to what has been mentioned above I am convinced that Alexios Komnenos was an outstanding and talented military commander. Since the early stages of his military career he was showing personal courage in close combat, tactical awareness and even broader strategic thinking thanks to which he outshone all his peers and even some of his elders. With a few notable exceptions discussed above he was able to win most of the campaigns, battles and skirmishes when in command. He campaigned throughout his life, and at the time of his death in 1118 the Byzantine Empire was secure and prosperous again. In fact, it would be unnatural if he won all battles during his career. There are many examples of brilliant military commanders in history of mankind who are still considered military geniuses in spite of the fact that they suffered severe defeats (e.g. Hannibal, Attilla, Belisarios, Herakleios, Napoleon or Erwin Rommel). In fact some authors imply that an outstanding military commander has to prove his worth by his capability to overcome the effect of a recent defeat and thus enhance his experience in the art of war. ${ }^{100}$ I think therefore, that the most serious defeats in the battles of Dyrrachion and Dristra do not prove bad or mediocre military command on Alexios Komnenos' part. They only show that Alexios Komnenos was a product of his own time. Beyond what was discussed above it is also worth noting that Alexios Komnenos' military education started in the period of decline of the Byzantine military power. The last truly large Byzantine army was gathered in the summer of 1071 and it was defeated by the Seljuk Turks at Mantzikert. Therefore, it was impossible for Alexios Komnenos (or indeed for any other equally or more talented Byzantine general of his generation) to acquire crucial experience how to lead large armies in a campaign. Before the first great test of his military skills under the walls of Dyrrachion in 1081, Alexios Komnenos did not lead a force larger than usual several hundred or thousand men. If we believe modern scholars he was leading probably 5,500 but in any case no more than 6,500 men during the battle of Kalavryai in 1078. ${ }^{101}$ At Dyrrachion his army was more than three times as large, at least 20,000 strong. Second time he was leading a similarly large force of 15,000 soldiers in the campaign against the Pechenegs in 1087. He was defeated in the battle of Dristra. To effectively lead such a force requires solid military experience which cannot be replaced by a mere talent and flawless theoretical knowledge. Thus, even in spite of the two serious defeats, Alexios Komnenos' military record counts among the best during the entire history of the Byzantine Empire.

location and directions in advance and deployed his troops accordingly. See Alexias, p. 285 (memathēkoi), 287 (memathēkoi, mathoien, mematēkotōn).

100 Kolias (1997: p. 162).

101 Haldon (2001: p. 128). 


\section{Abbreviations}

Ael.

Alexias

Attal.

Bryen.

Guil. Apul.

Chron. Pic.

Kekaumenos

Malaterra

Nestor

Ord. Vit.

Zonaras
Hahlweg, W. (Ed.) (1613). Tactica sive de aciebus constituendis ad Adrianum imperatorem. In Claudii Aeliani et Leoni imperatoris Tactica sive de instruendis aciebus. Leiden (Neudruck der Ausgabe, Osnabrück 1981).

Reinsch, D. R. - Kambylis, A. (Eds.) (2001). Anne Comnence Alexias. Corpus fontium historiæ byzantinæ. Berlin.

Bekker, I. (Ed.) (1853). Michaelis Attaliote Historia. Corpus scriptorum historiæ byzantinæ. Bonnæ.

Gautier, P. (Ed.) (1975). Hylé historias, Nicephori Bryenii Historiarum libri quattuor, Corpus fontium historiæ byzantinæ. Brussels. Mathieu, M. - Grégoire, H. (Eds.) (1961). La geste de Robert Guiscard. Palermo.

Domanovszky, A. (1937). Chronici hungarici compositio sæculi XIV. In Szentpétery, I. (Ed.) Scriptores rerum hungaricarum, Vol. I. Budapest.

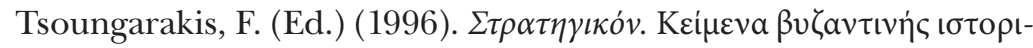
oppapias - 2. Athens.

Muratori, L. A. (Ed.) (1724). De rebus gestis Rogerii Calabriae et Siciliae comitis et Roberti Guiscardi ducis fratris eius. Rerum italicarum scriptores V (pp. 549-602). Milan.

Cross, S. H. - Sherbowitz-Wetzor, O. P. (Eds.) (1953). The Russian Primary Chronicle: Laurentian Text. Cambridge MA.

Chibnall, M. (Ed.) (1983). The ecclesiastical history of Orderic Vitalis. Volume II: Books III and IV. Oxford.

Pinder, M. (Ed.) (1897). Ioannis Zonare Epitome Historiarum. Corpus scriptorum historiæ byzantinæ. Tomus III. Bonnæ.

\section{Bibliography}

\section{Sources}

Hahlweg, W. (Ed.) (1613). Tactica sive de aciebus constituendis ad Adrianum imperatorem. In Claudii Aeliani et Leoni imperatoris Tactica sive de instruendis aciebus. Leiden (Neudruck der Ausgabe, Osnabrück 1981).

Bekker, I. (Ed.) (1853). Michaelis Attaliote Historia. Corpus scriptorum historiæ byzantinæ. Bonnæ.

Cross, S. H. - Sherbowitz-Wetzor, O. P. (Eds.) (1953). The Russian Primary Chronicle: Laurentian Text. Cambridge MA.

Gautier, P. (Ed.) (1975). Hylé historias, Nicephori Bryenii Historiarum libri quattuor, Corpus fontium historiæ byzantinæ. Brussels. 
Domanovszky, A. (1937). Chronici hungarici compositio sæculi XIV. In Szentpétery, I. (Ed.) Scriptores rerum hungaricarum, Vol. I. Budapest.

Chibnall, M. (Ed.) (1983). The ecclesiastical history of Orderic Vitalis. Volume II: Books III and IV. Oxford.

Mathieu, M. - Grégoire, H. (Eds.) (1961). La geste de Robert Guiscard. Palermo.

Muratori, L. A. (Ed.) (1724). De rebus gestis Rogerii Calabriae et Siciliae comitis et Roberti Guiscardi ducis fratris eius. Rerum italicarum scriptores V (pp. 549-602). Milan.

Pinder, M. (Ed.) (1897). Ioannis Zonarce Epitome Historiarum. Corpus scriptorum historiæ byzantinæ. Tomus III. Bonnæ.

Reinsch, D. R. - Kambylis, A. (Eds.) (2001). Anne Comnence Alexias. Corpus fontium historiæ byzantinæ. Berlin.

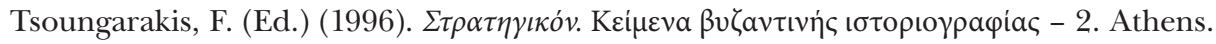

\section{Studies}

Alexopoulos, Th. (2008-2012). Using Ancient Military Handbooks to fight Medieval Battles: two

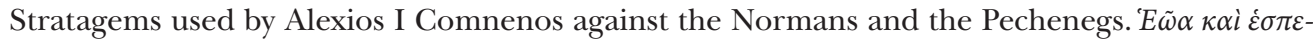
pía, 8, 47-71.

Angold, M. (1997). The Byzantine Empire, 1025 - 1204: a political history. London - New York.

Birkenmeier, J. W. (2002). The Development of the Comnenian Army 1081 - 1180. Leiden - Boston - Köln: Brill.

Blöndal, S. (1978). The Varangians of Byzantium. An aspect of byzantine military history. Translated, revised and rewritten by Benedikt S. Benedikz. Cambridge - Londýn - New York: Cambridge University Press.

Buckler, G. (1968). Anna Comnena, a Study. Oxford: Clarendon Press.

Bünemann, R (1997). Robert Guiscard 1015-1085. Ein Normanne erobert Süditalien. Köln-WeimarWien.

Dawson, T. - McBride, A. (2007). Byzantine Infantryman Eastern Roman Empire c. 900-1204. London: Osprey Publishing.

D’Amato, R. - Rava, G. (2010). The Varangian Guard 988-1453. London: Osprey Publishing.

Diaconu, P. (1970). Les Petchénègues au Bas-Danube. Bucharest.

Ducellier, A. (1981). La façade maritime de l'Albanie au Moyen âge. Durazzo et Valona du XIe au XVe siècle. Thessalonica.

Eads, V. (2005). Sichelgaita of Salerno: Amazon or Trophy Wife? The Journal of Medieval Military History, 3, 72-87.

Frankopan, P. (2007). Kinship and the Distribution of Power in Komnenian Byzantium. English Historical Review, 122, 1-34.

Frankopan, P. (2012). The First Crusade. The Call from the East. Cambridge MA.

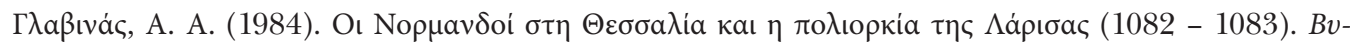
$\zeta \alpha v \tau \iota \alpha \kappa \alpha ́, 4,33-45$.

Haldon, J. (2001). The Byzantine Wars. Stroud. 
Haldon, J. (2002). Byzantium at War AD 600-1453. London: Osprey Publishing.

Hunger, H. (1978). Die hochsprachliche Profanliteratur der Byzantiner. Zweiter Band. Munich.

Chalandon, F. (1900). Essai sur le règne d’ Alexis Ir Comnène (1081-1118). Paris.

Chalandon, F. (1907). Histoire de la domination normande en Italie et en Sicile. Tome I. Paris.

Cheynet, J.-C. (1995). Les effectifs de l'armée byzantine au $\mathrm{X}^{\mathrm{e}}-\mathrm{XII}^{\mathrm{e}}$ s. Cahiers de la civilisation médiévale, 38, 319-335.

Cheynet, J.-C. (1996). Pouvoirs et contestations à Byzance (963-1210). Byzantina Sorbonensia 9. Paris.

Cheynet, J.-C. (2006). The Byzantine Aristocracy (8th - 13th centuries). In Cheynet, J.-C., The Byzantine Aristocracy and its Military Function (pp. 1-43). Aldershot: Variorum.

Йотов, Й. - Николов, Н. (2009). Походъ на Алексий I Комнин към Дръстър (1087 г.). Нови данни и интерпретация. In Пгтуванията в средневековна България. Материали от пгрвата наиионална конферениия „Пгтуване към България, пвтуванията в средневековна България и съвременният туризвм“ Шумен, 8.-11. 5. 2008 г. (pp. 432-447). Veliko Tărnovo.

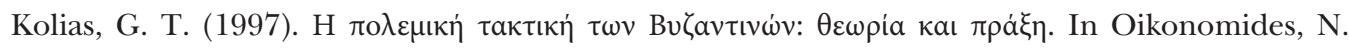

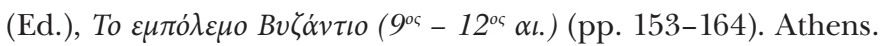

Kovács, S. (2014). The Cuman Campaigns in 1091. Golden Horde Review, 1(3), 174-189.

Kühn, H.-J. (1991). Die byzantinische Armee im 10. und 11. Jahrhundert. Studien zur Organisation der Tagmata. Wien.

Meško, M. (2007). Boje Byzancie s Pečenehmi o Trákiu v rokoch 1088 až 1091. Vojenská História, $11-1,3-27$.

Meško, M. (2011). Pečenežsko-byzantské dobrodružstvo uhorského krála Šalamúna (1083 - 1087). Konštantínove listy, 4, 77-94.

Meško, M. (2012). Obnova byzantskej moci na Balkáne za vlády Alexia I. Komnéna. Druhá byzantsko-pečenežská vojna (1083-1091). Nitra.

Meško, M. (2013). Pecheneg Groups in the Balkans (ca. 1053-1091) according to the Byzantine Sources. In F. Curta - B.-P. Maleon (Eds.), The Steppe Lands and the World beyond them. Studies in Honor of Victor Spinei on his 70th Birthday (pp. 179-205). Iaşi.

Mullett, M. - Smythe, D. (1996). Alexius Komnenos Papers of the Second Belfast Byzantine International Colloquium, 14-16 April 1989. Belfast.

Mullett, M. (1996). Introduction: Alexios the enigma. In M. Mullett - D. Smythe (Eds.), Alexius Komnenos Papers of the Second Belfast Byzantine International Colloquium, 14-16 April 1989 (pp. 1-11). Belfast.

Price, J. T. (2005). An Analysis of the Strategy and Tactics of Alexios I Komnenos, M. A. Thesis. Lubbock. Savvides, A. (2007). Byzantino-Normannica. The Norman Capture of Italy (to A.D. 1081) and the First Two Invasions in Byzantium (A.D. 1081-1085 and 1107-1108). Leuven-Paris-Dudley.

Shepard, J. (1993). The Uses of the Franks in Eleventh-Century Byzantium. Anglo-Norman Studies, $15,275-305$.

Skoulatos, B. (1990). Les personnages byzantins de l'Alexiade, analyse prosopographique de synthèse. Louvain.

Soustal, P. (1999). Thrakien (Thrakē, Rhodopē und Haimimontos). Tabula imperii byzantini, Band 6. Vienna.

Theotokis, G. (2014). The Norman Campaigns in the Balkans 1081-1108. Woodbridge. 
Tobias, N. (1979). The Tactics and Strategy of Alexius Comnenus at Calavrytae, 1078. Byzantine Studies, 6, 193-211.

Treatgold, W. T. (1995). Byzantium and its Army 284-1081. Stanford: University Press.

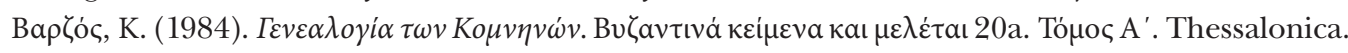

Mgr. Marek Meško, Ph.D. / menju50@gmail.com

Department of Classical Studies

Masaryk University, Faculty of Arts

Arna Nováka 1, 60200 Brno, Czech Republic 
